\title{
Kit systems for identifying Gram negative aerobic bacilli: report of the Welsh Standing Specialist Advisory Working Group in Microbiology
}

\author{
CHN BENNETT, DHM JOYNSON \\ From the Department of Pathology, General Hospital, Neath, West Glamorgan, Wales
}

SUMMARY Under the auspices of the Welsh Standing Specialist Advisory Working Group in Microbiology (WMG) 10 clinical microbiology laboratories in Wales undertook a collaborative study to assess 10 commercial kits for the identification of aerobic Gram negative bacilli. In excess of 1000 such strains were examined in parallel with each kit system. Accuracy, reproducibility of accuracy, and reproducibility alone were assessed, together with the cost effectiveness of the kits used. A ranking order of kit performance based on the above variables was drawn up.

Since the foundation of bacteriology as a science in the second half of the nineteenth century, the use of various substrate reactions as an aid to identification has been well exploited. This is particularly true of Enterobacteriaceae and other associated Gram negative aerobic bacilli. Antigenic analysis apart, biochemical reactions remain the primary means by which these organisms are identified.

The past decade has witnessed the introduction from commercial sources of several miniaturised kit identification systems designed to replace traditional methods of substrate testing. Prompted by these developments, the Standing Specialist Advisory Working Group in Microbiology of the Welsh Scientific Advisory Committee (WMG) decided to undertake a collaborative study to assess the value of the $10 \mathrm{kits}$, which were then available in the United Kingdom, for identifying Gram negative aerobic bacilli (Table 1). Of the kits listed, the API RapiD 20E, Minitek Enterobacteriaceae III, and Micro ID kits were designed to produce a result after four hours' incubation at $37^{\circ} \mathrm{C}$ : these three kits, together with the Titertek Enterobac, were not intended for the identification of oxidase positive, afermentative, Gram negative aerobic rods.

Previously published reports have included a study of six commercial systems by Smith, ${ }^{1}$ five systems by Nord et al, ${ }^{2}$ comparisons between two commercial systems and conventional media by Barry et al, ${ }^{3}$ and comparisons between a single commercial kit and tra-

Accepted for publication 23 January 1986 ditional substrates by Holmes et $a l^{4}{ }^{4}$ and a comprehensive review article by D'Amato et al. ${ }^{5}$ We could find no reference to the kind of large scale collaborative and comparative study that we propose.

\section{Material and methods}

A detailed protocol was agreed by the WMG and the kit manufacturers to: evaluate the accuracy and reproducibility of the systems; attempt to assess the cost effectiveness of the systems.

The Neath laboratory, having been designated as the source laboratory, collected 860 isolates (representing 48 taxa) of aerobic Gram negative bacilli from within West Glamorgan and other parts of Wales (Table 2). Strains were identified using the API 20E system, subcultured on to Dorset egg medium, and held at room temperature until required. A preprinted index card was used to record the source of the strain, the profile score, and the identification: these cards were subsequently used to record the results from participating laboratories and formed the manual data base used in compiling a series of progress reports considered by the Working Group throughout the study.

In addition to the clinical series, a collection of control strains were assembled from the National Collection of Type Cultures (NCTC), the American Type Culture Collection (ATCC), and the Microbiology Quality Assessment Scheme (MQAS), supplemented with local isolates of Salmonella spp and Yersinia spp. The identities of Yersinia spp were confirmed by the respective PHLS reference laboratories. The control 
Table 1 Kit systems used

\begin{tabular}{|c|c|c|}
\hline Source & Product name & Abbreviation \\
\hline $\begin{array}{l}\text { API Laboratory Products } \\
\text { API Laboratory Products } \\
\text { Becton Dickinson } \\
\text { Becton Dickinson } \\
\text { Roche Products }\end{array}$ & $\begin{array}{l}\text { API 20E } \\
\text { API RapiD 20E } \\
\text { MINITEK Enterobacteriaceae II } \\
\text { MINITEK Enterobacteriaceae III } \\
\text { OXI/FERM ENTEROTUBE II }\end{array}$ & $\begin{array}{l}\text { API 20E } \\
\text { API RAP } \\
\text { ENT II } \\
\text { ENT III } \\
\text { OXI ENT }\end{array}$ \\
\hline $\begin{array}{l}\text { LIP Services } \\
\text { Seward Laboratory } \\
\text { General Diagnostics } \\
\text { Flow Laboratories } \\
\text { Cathra International }\end{array}$ & $\begin{array}{l}\text { MICROBACT 24E } \\
\text { SENSITITRE ENTERIC } \\
\text { IDENTIFICATION PLATE } \\
\text { MICRO ID } \\
\text { TITERTEK ENTEROBAC } \\
\text { REPLIDEX }\end{array}$ & $\begin{array}{l}\text { MIC 24E } \\
\text { SEN EIP } \\
\text { MIC ID } \\
\text { TTK EBC } \\
\text { REPDEX }\end{array}$ \\
\hline
\end{tabular}

Although all systems are designed to identify members of the family Enterobacteriaceae, other related extra taxa, which include oxidase positive afermenting organisms, are not handled by four of the systems: the API RapiD 20E, MINITEK Enterobacteriaceae III,

MICRO ID, and the TITERTEK ENTEROBAC. Because of this constraint, it was necessary to account for this in reporting results.

series was derived from the 63 strains representing 40 taxa (Table 3).

It was agreed that the source laboratory should use the API 20E kit, although the remaining participating laboratories were randomly assigned a particular kit by means of a draw. Apart from the considerable experience with the API $20 \mathrm{E}$ kit by the source laboratory, experience with the other kits was minimal or nil. The agreed protocol, however, contained provision for full "on site" training to be given by the manufacturers and for their representatives to ensure close liaison with the respective laboratories throughout the study. At weekly intervals 24 cultures were selected from the clinical series together with one control culture. After subculture on MacConkey agar to check purity and viability a single colony was suspended in $5 \mathrm{ml}$ of sterile distilled water. This suspension was used to inoculate an API 20E strip, a pair of glucose oxidation/fermentation media, 10 nutrient agar slopes, and a segment of a MacConkey agar plate as a further purity and viability check. Preprinted, self adhesive, serially numbered labels were used to identify each culture, and the same numbered label affixed to the index card. After incubation of all cultures at $37^{\circ} \mathrm{C}$ for 24 hours the MacConkey plate was inspected for purity and viability. If satisfactory the API 20E strip was dosed with the appropriate reagents and the results read, together with the reaction of the pair of oxidation/fermentation media. The profile score obtained was compared with the scores

Table 2 Clinical isolates: taxa and numbers tested

\begin{tabular}{|c|c|c|c|}
\hline Taxon & No & Taxon & No \\
\hline $\begin{array}{l}\text { Achromobacter xylosoxidans } \\
\text { Acinetobacter aniltratus } \\
\text { Acinetobacter iwoffii } \\
\text { Aeromonas hydrophila } \\
\text { Alcaligenes spp } \\
\text { CDC Group IV-E } \\
\text { Citrobacter spp } \\
\text { Citrobacter diversus } \\
\text { Citrobacter freundii } \\
\text { Enterobacter cloacae } \\
\text { Enterobacter agglomerans } \\
\text { Enterobacter aerogenes } \\
\text { Enterobacter gergoviae } \\
\text { Enterobacter sakazakii } \\
\text { Edwardsiella tarda } \\
\text { Escherichia coli } \\
\text { Escherichia coli lysine negative, }\end{array}$ & $\begin{array}{r}1 \\
23 \\
4 \\
2 \\
11 \\
1 \\
2 \\
15 \\
42 \\
52 \\
9 \\
10 \\
1 \\
3 \\
2 \\
209\end{array}$ & $\begin{array}{l}\text { Plesiomonas shigelloides } \\
\text { Proteus mirabilis } \\
\text { Proteus morganii } \\
\text { Proteus vulgaris } \\
\text { Providencia alcalifaciens } \\
\text { Providencia rettgeri } \\
\text { Providencia stuartii } \\
\text { Pseudomonas spp } \\
\text { Pseudomonas aeruginosa } \\
\text { Pseudomonas fluorescens } \\
\text { Pseudomonas cepacia } \\
\text { Pseudomonas maltophilia } \\
\text { Pseudomonas stutzeri } \\
\text { Salmonella spp } \\
\text { Salmonella typhi } \\
\text { Serratia liquefaciens }\end{array}$ & $\begin{array}{r}2 \\
58 \\
40 \\
14 \\
9 \\
3 \\
36 \\
1 \\
18 \\
7 \\
2 \\
5 \\
2 \\
25 \\
2 \\
9\end{array}$ \\
\hline $\begin{array}{l}\text { ornithine negative } \\
\text { Escherichia coli Alkalescens-dispar } \\
\text { Escherichia coli hydrogen sulphide positive } \\
\text { Hafnia alvei } \\
\text { Klebsiella pneumoniae } \\
\text { Klebsiella oxytoca } \\
\text { Klebsiella ozaenae } \\
\text { Pasteurella aerogenes }\end{array}$ & $\begin{array}{r}20 \\
24 \\
1 \\
22 \\
91 \\
20 \\
2 \\
1\end{array}$ & $\begin{array}{l}\text { Serratia marescens } \\
\text { Shigella spp } \\
\text { Shigella boydii } \\
\text { Shigella dysenteriae } \\
\text { Shigella flexneri } \\
\text { Shigella sonnei } \\
\text { Yersinia enterocolitica } \\
\text { Yersinia pseudotuberculosis } \\
\text { Total clinical isolates }\end{array}$ & $\begin{array}{r}28 \\
1 \\
5 \\
1 \\
1 \\
6 \\
11 \\
6 \\
860\end{array}$ \\
\hline
\end{tabular}


Table 3 Control strains and sources used

\begin{tabular}{|c|c|c|c|}
\hline Organism & Source & Organism & Source \\
\hline $\begin{array}{l}\text { Acinetobacter calcoaceticus } \\
\text { Aeromonas hydrophila } \\
\text { Alcaligenes faecalis } \\
\text { Alcaligenes odorans } \\
\text { Citrobacter ballerupensis* } \\
\text { Citrobacter freundii } \\
\text { Citrobacter freundii } \\
\text { Edwardsiella tarda } \\
\text { Enterobacter aerogenes } \\
\text { Enterobacter agglomerans } \\
\text { Enterobacter cloacae } \\
\text { Enterobacter cloacae } \\
\text { Escherichia alkalescenst } \\
\text { Escherichia coli } \\
\text { Escherichia coli } \\
\text { Escherichia coli } \\
\text { Escherichia dispart } \\
\text { Hafnia alvei } \\
\text { Klebsiella aerogenes } \\
\text { Klebsiella aerogenes } \\
\text { Klebsiella edwardsii (var) atlantae } \\
\text { Klebsiella ozaenae } \\
\text { Klebsiella pneumoniae } \\
\text { Klebsiella pneumoniae } \\
\text { Klebsiella pneumoniae } \\
\text { Klebsiella rhinoscleromatis } \\
\text { Plesiomonas shigelloides } \\
\text { Proteus mirabilis } \\
\text { Proteus mirabilis } \\
\text { Proteus mirabilis } \\
\text { Proteus morganii }\end{array}$ & $\begin{array}{l}\text { NCTC } 7844 \\
\text { NCTC } 8049 \\
\text { NCTC } 8764 \\
\text { NCTC } 10416 \\
\text { NCTC } 6021 \\
\text { MQAS } 673 \\
\text { NCTC } 9750 \\
\text { NCTC } 1036 \\
\text { NCTC } 10006 \\
\text { MQAS } 632 \\
\text { ATCC } 23355 \\
\text { MQAS } 644 \\
\text { NCTC } 1601 \\
\text { NCTC } 86 \\
\text { ATCC } 12228 \\
\text { MQAS } 649 \\
\text { NCTC } 7721 \\
\text { NCTC } 5678 \\
\text { NCTC } 5005 \\
\text { NCTC } 8172 \\
\text { NCTC } 10896 \\
\text { NCTC } 5050 \\
\text { ATCC } 23357 \\
\text { MQAS } 644 \\
\text { NCTC } 9633 \\
\text { NCTC } 50465 \\
\text { NCTC } 10360 \\
\text { MQAS } 669 \\
\text { MQAS } 680 \\
\text { NCTC } 7827 \\
\text { NCTC } 235\end{array}$ & $\begin{array}{l}\text { Proteus rettgeri } \\
\text { Proteus vulgaris } \\
\text { Proteus vulgaris } \\
\text { Providencia alcalifaciens } \\
\text { Providencia stuartii } \\
\text { Pseudomonas aeruginosa } \\
\text { Pseudomonas aeruginosa } \\
\text { Pseudomonas aeruginosa } \\
\text { Pseudomonas cepacia } \\
\text { Pseudomonas fluorescens } \\
\text { Salmonella arizona } \\
\text { Salmonella bovis morbificans } \\
\text { Salmonella enteritidis } \\
\text { Salmonella typhi } \\
\text { Salmonella typhi } \\
\text { Salmonella typhimurium } \\
\text { Salmonella typhimurium } \\
\text { Serratia marescens } \\
\text { Shigella boydii serotype } 1 \\
\text { Shigella dysenteriae serotype } 4 \\
\text { Shigella flexneri serotype } 4 b \\
\text { Shigella sonnei } \\
\text { Shigella sonnei } \\
\text { Shigella sonnei } \\
\text { Vibrio sp (NAG) } \\
\text { Yersinia enterocolitica } \\
\text { Yersinia enterocolitica } \\
\text { Yersinia enterocolitica } \\
\text { Yersinia enterocolitica } \\
\text { Yersinia fredericksensii } \\
\text { Yersinia fredericksensii } \\
\text { Yersinia pseudotuberculosis }\end{array}$ & $\begin{array}{l}\text { NCTC } 7475 \\
\text { ATCC } 6380 \\
\text { NCTC } 10020 \\
\text { NCTC } 10286 \\
\text { NCTC } 10318 \\
\text { NCTC } 10701 \\
\text { MQAS } 627 \\
\text { ATCC } 14207 \\
\text { NCTC } 10661 \\
\text { MQAS } 650 \\
\text { NCTC } 8297 \\
\text { MQAS } 661 \\
\text { MQAS } 649 \\
\text { West Glam } 6 \\
\text { West Glam } 23 \\
\text { MQAS } 632 \\
\text { ATCC } 14028 \\
\text { ATCC } 8100 \\
\text { NCTC } 9327 \\
\text { NCTC } 9759 \\
\text { MQAS } 662 \\
\text { MQAS } 669 \\
\text { MQAS } 764 \\
\text { MQAS } 719 \\
\text { MQAS } 698 \\
\text { West Glam } 40 \\
\text { MQAS } 776 \\
\text { West Glam } 65 \\
\text { West Glam 90 } \\
\text { West Glam } 98 \\
\text { West Glam } 104 \\
\text { West Glam } 25\end{array}$ \\
\hline
\end{tabular}

* Now classified as a strain of Citrobacer freundii (NCTC, personal communication).

+ Now regarded as strains of Escherichia coli.

contained in the manufacturers' profile index. Any additional tests indicated in the index were undertaken and the final identification, together with the profile score recorded on the relevant index card. In accordance with the manufacturers' instructions, strains showing no utilisation of glucose and less than two other positive reactions were returned to the incubator for a further 24 hours before reagents were added. The nutrient agar slopes were inspected for evidence of visible growth, the caps tightened, and sets of 25 cultures, together with a results sheet were suitably packed and despatched by post to participating laboratories. Returned results, comprising profile score and identification, were entered on the respective index cards. This data was subsequently transcribed for computer input and so stored for future detailed analysis.

The identities of all cultures used in the study were not known by the participating laboratories until the study had been completed.

\section{Results}

It was agreed by the WMG that the results should be analysed in three ways: how well a kit performed in correctly identifying a strain; the reproducibility of accuracy achieved; the reproducibility achieved, irrespective of accuracy.

Results of both clinical and control series were analysed and presented at both genus and species levels of identification. To compensate for those kits which were not intended to identify the oxidase positive afermenters - that is, the API RapiD 20E, Minitek Enterobacteriaceae III, and Titertek Enterobac, the appropriate figures were corrected so as to exclude such organisms.

Table 4 shows identification performance achieved with the control strains and Table 5 kit performance with the 860 clinical strains.

Reproducibility of accuracy together with reproducibility alone were determined from results obtained by the issue on three separate occasions during the study of 60 of the control strains. The identity and origin of these strains were unknown to the participants. Results were recorded (in percentage terms) of the number of times reproducibility of accuracy was achieved (Table 6). Similarly, Table 7 shows the reproducibility, irrespective of accuracy.

The participating laboratories completed a questionnaire designed to provide information on the tim- 
Table 4 Accuracy of performance: control series

\begin{tabular}{|c|c|c|}
\hline \multirow[t]{2}{*}{ Kit } & \multicolumn{2}{|c|}{ Percentage } \\
\hline & Genus & Species \\
\hline $\begin{array}{l}\text { API 20E } \\
\text { API RapiD 20E } \\
\text { MINITEK Enterobacteriaceae II } \\
\text { MINITEK Enterobacteriaceae III } \\
\text { OXI/FERM ENTEROTUBE II } \\
\text { MICROBACT 24E } \\
\text { REPLIDEX } \\
\text { SENSITITRE EIP (AP60) } \\
\text { MICRO ID } \\
\text { TITERTEK ENTEROBAC }\end{array}$ & $\begin{array}{l}96 \cdot 3 \\
89 \cdot 3 \\
85 \cdot 5 \\
66 \cdot 0 \\
85 \cdot 9 \\
81 \cdot 4 \\
64 \cdot 7 \\
94 \cdot 1 \\
79 \cdot 3 \\
88 \cdot 8\end{array}$ & $\begin{array}{l}95 \cdot 0 \\
81 \cdot 3 \\
78 \cdot 2 \\
54 \cdot 3 \\
76 \cdot 4 \\
73 \cdot 3 \\
57 \cdot 4 \\
85 \cdot 9 \\
68 \cdot 4 \\
82 \cdot 0\end{array}$ \\
\hline
\end{tabular}

ing of setting up and reading tests, the cost of kits, shelf life, user problems encountered, problems of nomenclature, and microbiological safety.

\section{Discussion}

Examination of the results provided evidence for the ranking of the 10 kits examined in terms of percentage accuracy at both levels of identification. With the control series the best performing kits at genus and species levels were the API 20E and the Sensititre EIP kit, with the Replidex and Minitek Enterbacteriaceae

Table 5 Accuracy of performance: clinical series

\begin{tabular}{lll}
\hline Kit & \multicolumn{2}{l}{ Percentage } \\
\cline { 2 - 3 } & Genus & Species \\
\hline API 20E & $99 \cdot 5$ & $99 \cdot 3$ \\
API RapiD 20E & 87.0 & 84.9 \\
MINITEK Enterobacteriaceae II & 93.1 & 84.5 \\
MINITEK Enterobacteriaceae III & 80.0 & $63 \cdot 0$ \\
OXI/FERM ENTEROTUBE II & 81.4 & 76.7 \\
MICROBACT 24E & $81 \cdot 5$ & $70 \cdot 6$ \\
REPLIDEX & 68.0 & $56 \cdot 5$ \\
SENSITITRE EIP (AP60) & $91 \cdot 6$ & 78.4 \\
MICRO ID & 88.1 & $77 \cdot 0$ \\
TITERTEK ENTEROBAC & 85.4 & 85.0 \\
\hline
\end{tabular}

Table 6 Reproducibility of accuracy: control series

\begin{tabular}{lll}
\hline Kit & \multicolumn{2}{l}{ Percentage } \\
\cline { 2 - 3 } & Genus & Species \\
\hline API 20E & 96.6 & 90.0 \\
API RapiD 20E & 80.0 & 72.7 \\
MINITEK Enterobacteriaceae II & 76.6 & 61.6 \\
MINITEK Enterobacteriaceae III & 41.8 & 27.3 \\
OXI/FERM ENTEROTUBE II & 71.6 & 55.0 \\
MICROBACT 24E & 65.0 & 51.6 \\
REPLIDEX & 45.0 & 36.6 \\
SENSITITRE EIP (AP60) & 83.3 & 71.6 \\
MICRO ID & 41.5 & 33.9 \\
TITERTEK ENTEROBAC & 79.2 & 58.5 \\
\hline
\end{tabular}

III kits performing poorly, and the remaining kits occupying the middle ground. A similar order of performance in terms of reproducibility of accuracy and reproducibility alone was observed with the control strains.

With the clinical series the identification achieved by the source laboratory using the API 20E kit was used as a reference point. Our experience with the control series supports this standpoint and accords with the views expressed by Hayek and Willis ${ }^{6}$ regarding the API 20E kit. In only nine instances (four strains at genus level and five at species level)

Table 7 Reproducibility, irrespective of accuracy: control series

\begin{tabular}{|c|c|c|}
\hline \multirow[t]{2}{*}{ Kit } & \multicolumn{2}{|c|}{ Percentage } \\
\hline & Genus & Species \\
\hline $\begin{array}{l}\text { API 20E } \\
\text { API RapiD 20E } \\
\text { MINITEK Enterobacteriaceae II } \\
\text { MINITEK Enterobacteriaceae III } \\
\text { OXI/FERM ENTEROTUBE II } \\
\text { MICROBACT 24E } \\
\text { REPLIDEX } \\
\text { SENSITITRE EIP (AP60) } \\
\text { MICRO ID } \\
\text { TITERTEK ENTEROBAC }\end{array}$ & $\begin{array}{l}98 \cdot 3 \\
85 \cdot 5 \\
86 \cdot 0 \\
53 \cdot 7 \\
76 \cdot 6 \\
66 \cdot 6 \\
48 \cdot 3 \\
86 \cdot 6 \\
43 \cdot 4 \\
79 \cdot 2\end{array}$ & $\begin{array}{l}93 \cdot 3 \\
81 \cdot 8 \\
73 \cdot 3 \\
35 \cdot 2 \\
63 \cdot 0 \\
56 \cdot 6 \\
43 \cdot 3 \\
78 \cdot 3 \\
37 \cdot 3 \\
64 \cdot 1\end{array}$ \\
\hline
\end{tabular}

Table 8 Summary of accuracy of performance

\begin{tabular}{|c|c|c|c|c|}
\hline \multirow[t]{3}{*}{ Kit } & \multicolumn{4}{|c|}{ Percentage } \\
\hline & \multicolumn{2}{|c|}{ Control } & \multicolumn{2}{|c|}{ Clinical } \\
\hline & Genus & Species & Genus & Species \\
\hline $\begin{array}{l}\text { API 20E } \\
\text { API RapiD 20E } \\
\text { MINITEK Enterobacteriaceae II } \\
\text { MINITEK Enterobacteriaceae III } \\
\text { OXI/FERM ENTEROTUBE II } \\
\text { MICROBACT 24E } \\
\text { REPLIDEX } \\
\text { SENSITITRE EIP (AP60) } \\
\text { MICRO ID } \\
\text { TITERTEK ENTEROBAC }\end{array}$ & $\begin{array}{l}96 \cdot 3 \\
89 \cdot 3 \\
85 \cdot 5 \\
66 \cdot 0 \\
85 \cdot 9 \\
81 \cdot 4 \\
64 \cdot 7 \\
94 \cdot 1 \\
79 \cdot 3 \\
88 \cdot 8\end{array}$ & $\begin{array}{l}95 \cdot 0 \\
81 \cdot 3 \\
78 \cdot 2 \\
54 \cdot 3 \\
76 \cdot 4 \\
73 \cdot 3 \\
57 \cdot 4 \\
85 \cdot 9 \\
68 \cdot 4 \\
82 \cdot 0\end{array}$ & $\begin{array}{l}99 \cdot 5 \\
87 \cdot 0 \\
93 \cdot 1 \\
80 \cdot 0 \\
81 \cdot 4 \\
81 \cdot 5 \\
68 \cdot 0 \\
91 \cdot 6 \\
88 \cdot 1 \\
85 \cdot 4\end{array}$ & $\begin{array}{l}99 \cdot 3 \\
84 \cdot 9 \\
84 \cdot 5 \\
63 \cdot 0 \\
76 \cdot 7 \\
70 \cdot 6 \\
56 \cdot 5 \\
78 \cdot 4 \\
77 \cdot 0 \\
85 \cdot 0\end{array}$ \\
\hline
\end{tabular}


Table 9 Identification failures in control series

\begin{tabular}{|c|c|c|c|}
\hline \multirow[t]{2}{*}{ Kit } & \multicolumn{3}{|l|}{ Percentage } \\
\hline & Pathogens* & Non-pathogenst & Total $\$$ \\
\hline $\begin{array}{l}\text { API } 20 \mathrm{E} \\
\text { API RapiD 20E } \\
\text { MINITEK Enterobacteriaceae II } \\
\text { MINITEK Enterobacteriaceae III } \\
\text { OXI/FERM ENTEROTUBE II } \\
\text { MICROBACT 24E } \\
\text { REPLIDEX } \\
\text { SENSITITRE EIP (AP60) } \\
\text { MICRO ID } \\
\text { TITERTEK ENTEROBAC }\end{array}$ & $\begin{array}{r}0 \cdot 0 \\
6 \cdot 6 \\
6 \cdot 6 \\
28 \cdot 6 \\
17 \cdot 1 \\
19 \cdot 7 \\
51 \cdot 3 \\
3 \cdot 9 \\
18 \cdot 4 \\
6 \cdot 6\end{array}$ & $\begin{array}{r}0 \cdot 0 \\
3 \cdot 4 \\
6 \cdot 2 \\
16 \cdot 6 \\
1 \cdot 4 \\
2 \cdot 8 \\
5 \cdot 6 \\
3 \cdot 4 \\
9 \cdot 0 \\
2 \cdot 8\end{array}$ & $\begin{array}{r}0 \cdot 0 \\
4 \cdot 5 \\
6 \cdot 3 \\
20 \cdot 4 \\
6 \cdot 8 \\
8 \cdot 6 \\
21 \cdot 3 \\
3 \cdot 6 \\
12 \cdot 2 \\
4 \cdot 1\end{array}$ \\
\hline
\end{tabular}

*Pathogens incorrectly identified $(\mathrm{n}=79)$.

+ Non-pathogens identified as pathogens $(n=142)$.

$\ddagger$ Total failures of identification $(n=221)$.

was the identification obtained by the source laboratory, with the 860 clinical isolates being totally at variance with the identification obtained by the other participants. These strains were recorded as out of agreement, thus giving the API 20E kit less than 100 per cent accuracy of identification (Table 5). Examination of results from the clinical series provides evidence of a similar ranking to that obtained with the control series. From a summary of results of performance accuracy of both clinical and control series, however, it seems that a marginal increase in performance was achieved by all kits in respect of the clinical series (Table 8). This increase may relate to the larger number of strains examined in the clinical series, or the fact that roughly $25 \%$ of these comprised strains of Escherichia coli, or both factors: additionally, stock cultures (comprising most of the control series) are known to have impaired enzyme activity, resulting in aberrant biochemical activity in substrates. Of particular concern to the WMG were the failures of identification in the control series, and these were considered from two aspects.

Firstly, that strains with clinical or epidemiological importance were not correctly identified due to misidentification or non-identification. Genera regarded of critical importance in this context were Edwardsiella, Plesiomonas, Salmonella or Arizona, Shigella, Yersinia, and Vibrio. Secondly, that organisms were not correctly identified as nonpathogens either by non-identification or misidentifying a non-pathogen-such as Ecoli incorrectly identified as Shigella flexneri.

Table 9 shows the identification failures in the control series and specific examples included the following: $S$ flexneri misidentified as $E$ coli on one occasion and as a Yersinia on another occasion by the same kit, $S$ dysenteria misidentified by three of the kits as Acinetobacter iwoffi, Proteus morganii, and a Salmonella $\mathrm{sp}$, respectively. Examples of non-pathogens identified as pathogens included Klebsiella pneumoniae misidentified as Yersinia pseudotuberculosis on one occasion and as a Salmonella sp on the second occasion by the same kit. Serratia marcescens was misidentified as a Salmonella sp and subsequently again misidentified as Yersinia pseudotuberculosis by another kit.

In evaluating the activity analysis questionnaires, it was evident that a valid objective assessment of timings was impractical. Unit costs at the time of the study (excluding available discount) ranged from 16 pence for the Replidex kit to 196 pence for the Micro ID kit, with an average unit cost of 120 pence. Most kits could be stored at between $2^{\circ} \mathrm{C}$ and $8^{\circ} \mathrm{C}$, but for the Titertek Enterobac storage at $-20^{\circ} \mathrm{C}$ was recommended. Shelf life varied from two months (Replidex kit) to two years (Sensititre EIP); most kits had an average shelf life of one year.

Microbiological safety was assessed with particular reference to aerosol and droplet dispersal, with the exception of the inbuilt inoculation wire of the Oxi/Ferm Enterotube II, and inoculation of the kits was by means of a pipette. Using the accepted level of care, no evidence of environmental contamination could be detected with any of the kits. Autoclaving or incineration, or both, provided safe after use disposal of all kits examined.

User problems reported were largely confined to initial difficulties in interpretation of colour changes with the carbohydrates, decarboxylases, and the arginine dihydrolase, but these diminished with increasing experience. The Replidex kit, however, caused persistent problems of interpretation due to colour diffusion around adjacent discs.

Problems of nomenclature were few, apart from the fact that none of the data bases took account of the Cowan ${ }^{7}$ classification of the Klebsiellas, and some data bases classified Salmonella of subgenus III as Arizona sp. 
The WMG believe it to be axiomatic that potential users of identification kits should require accuracy and that reproducibility is of paramount importance, with cost effectiveness a secondary consideration. The WMG also believed that the ideal kit should speciate not only the Enterobacteriaceae but should also identify the associated Gram negative oxidase positive afermenting rods. The results of this collaborative study suggest that only two kits approached this ideal, the API 20E and Sensititre EIP. Other workers, however, may not agree with this ideal and will be prepared to sacrifice some degree of accuracy and reproducibility for other perceived benefits. For example, some may be satisfied with genus level identification, particularly if the answer is available in four hours. Others may be content to reserve the use of these kits only for the identification of the Enterobacteriaceae and use more conventional methods when dealing with the oxidase positive afermenting aerobic Gram negative rods.

The reasons for the less than ideal performance of some kits examined in this study was not part of our remit, but it is clear that expansion of data bases could be helpful in improving performance, as could a review of the test substrates used.

Our thanks are due to the members of the Welsh Standing Specialist Advisory Working Group in Microbiology for their active support and all those laboratories in Wales who collaborated in the work. We are indebted to Mrs Gillian Webber for expert secretarial assistance.

The study was funded by the Supply Division, Department of Health and Social Security.
Members of the Welsh Standing Specialist Working Group in Microbiology (WMG) and the Participating Laboratories:

Dr DHM Joynson (Chairman), Neath; Mr TC Fitzgerald (Secretary), Penarth; Mr CHN Bennett, Neath; Dr JMH Boyce, Pontypridd; Mr R Brooks, Swansea; Dr P Callaghan, Aberystwyth; Mr FCK George, Neath; Mrs SE Gladwin, Abergavenny; Dr J Glencross, Newport; Dr AJ Howard, Bangor; Dr CHL Howells, Cardiff; Mr B Hughes, Aberystwyth; Dr FB Jackson, Bodelwyddan; Dr PA Jenkins, Cardiff; Mr GH Lowe, Cardiff; Dr H Morgan, Carmarthen; Mr RJ Powell, Pontypridd; Dr CD Ribiero, Cardiff; Mr MS Smith, Cardiff; Dr JM Stark, Cardiff; Mr KL Thomas, Bodelwyddan; Dr J Pritchard (in attendance), Welsh Office.

\section{References}

${ }^{1}$ Smith PB. Performance of six bacterial identification systems. Atlanta: US Department of Health, Education and Welfare, 1975.

${ }^{2}$ Nord C-E, Linberg AA, Dahlback A. Evaluation of five test kitsAPI, Auxotab, PathoTec, and R/B for identification of Enterobacteriaceae. Med Microbiol Immunol 1974;159:211.

${ }^{3}$ Barry AL, Badal RE. Rapid identification of Enterobacteriaceae with the Micro-ID system versus API 20E and conventional media. J Clin Microbiol 1979;10:293-8.

${ }^{4}$ Holmes B, Willcox RR, Lapage SP. Identification of Enterobacteriaceae by the API 20 E system. J Clin Pathol 1978; 31:22-30.

${ }^{5}$ D'Amato RF, Holmes B, Buttone EJ. The systems approach to diagnostic microbiology. CRC Crit Rev 1981;9:1-44.

${ }^{6}$ Hayek LJ, Willis GW. Identification of the Enterobacteriaceae: a comparison of the Enterotube II with the API 20E. J Clin Pathol 1984;37:344-7.

${ }^{7}$ Cowan ST, Steel KG. Manual for the Identification of Medical Bacteria. 2nd ed. London: Cambridge University Press, 1974.

Requests for reprints to: Dr DHM Joynson, Consultant Microbiologist, Department of Pathology, Neath General Hospital, Neath, Glamorgan SA11 2LQ, England. 